\title{
Impact of Some Organic Manure with Chemical Fertilizers on Growth and Yield of Broad Bean (Vicia faba L.) Grown in Newly Cultivated Land
}

\author{
Mohamed A. Seif El-Yazal \\ Botany Department, Faculty of Agriculture, Fayoum University, Fayoum 63514, Egypt \\ Corresponding author e.mail: mas04@fayoum.edu.eg
}

Keywords: broad bean (Vicia faba L.), soil salinity, poultry manure, farmyard manure, growth, seed yield, chemical composition.

\begin{abstract}
The possibility of improving growth and yield of broad bean (Vicia faba L.) plants grown in newly cultivated land was conducted during the two successive seasons of 2018 and 2019. For achieving this aim, broad bean plants were fertilized with different rates of organic fertilizers (poultry or farmyard manures) and minerals (NPK). Different growth parameters, chemical constituent and yield were determined in this study. The results indicated that organic fertilized plants achieved higher values of different growth parameters (plant height, number of branches, plant leaf lets blade area and dry weight / plant) and yield and its components (number of pods / plant, no of seeds / pod, weight of seeds / pod, weight of 100 seeds and weight of seeds / plant). The best results were obtained when the plants were fertilized with high rate of poultry manure ( 8 tons) and NPK fertilizers $(50 \mathrm{~kg}$ ammonium nitrate $33.5 \%+200 \mathrm{~kg}$ superphosphate $15.5 \%+50 \mathrm{~kg}$ potassium Sulphate $48 \%$ ). The present results also show that the concentration of chlorophyll. A, b, carotenoids, crude proteins, total free amino acids, total carbohydrates, total sugars, reducing sugars an non soluble carbohydrates recorded the higher values in both leaves and seeds of those plants fertilized with either poultry or farmyard manures when compared with those fertilized with NPK. The present study clearly shows that the best effect was recorded by supplying the plants with poultry manure $(8$ tons + NPK nutrients $(50 \mathrm{~kg}$ ammonium nitrate $33.5 \%+200 \mathrm{~kg}$ superphosphate $15.5 \%+50 \mathrm{~kg}$ potassium Sulphate $48 \%$ ) .
\end{abstract}

\section{Introduction}

Broad bean (Vicia faba L.) is a famous winter leguminous crops in Iraq. It is considered as a good source of vegetarian protein for human consumption, and it is cultivated in crop rotations to improve soil properties [1]. Application of chemical and organic fertilizers is an essential process in plant management. Adequate fertilizers led to increase the crop yields, improves the nutrient element concentration in plant tissue and soil macro and micro nutrient status. Chemical fertilizers are expensive and have harmful effects on the environment [2], therefore recommended the addition of organic matter (animals manure) as an alternative to chemical fertilizers [3]. The addition of organic fertilizers efficiently ensures high production and continuous crops by improving soil properties and increase roots development and soil microorganism's activity [4\&5]. Some researchers reported that application of organic manure (poultry or farmyard manure) increased pod yield, N, P, Ca, Ma, Zn and $\mathrm{Cu}$ concentration and their uptake plants $[6,7,8,9,10,11,12,13,14 \& 15]$.

Because of the importance effect of fertilizer types, especially organic fertilizers in influencing the quantity and quality of yield as well as external and physiological aspects of plant growth, this study was carried out to compare the effect of some organic fertilizers (poultry or farmyard manure) in combination with chemical fertilizers on growth, yield and chemical constituents of broad bean plants grown in the newly reclaimed soil.

\section{Materials and Methods}

The field experiment was carried out in a calcareous soil in the Farm in Demo, Fayoum, Governorate during two successive seasons 2017 / 2018 and 2018 / 2019. Soil properties of the experimental soil and chemical analysis of the studied organic fertilizers are shown in Table 1. 
Two types of organic fertilizers i.e., poultry manure and farmyard manure were used at the rates of 4 and 8 tons / fed and added as pre-sowing application. The amount of mineral fertilizers were used at the rates of 0,50 and $100 \%$ from N, P, K from the rate recommended by the Egyptian Ministry of Agriculture $(0.0,25$ and $50 \mathrm{~kg} / \mathrm{fed}$. of ammonium nitrate $33.5 \% \mathrm{~N}, 0.0,100$ and $200 \mathrm{~kg} /$ fed. calcium superphosphate $15.5 \% \mathrm{P}_{2} \mathrm{O}_{5}$ and $0.0,25$ and $50 \mathrm{~kg} / \mathrm{fed}$. potassium sulphate $48 \% \mathrm{~K}_{2} \mathrm{O}$ for broad bean plants respectively.

Table 1. The chemical properties of experimental soil and organic fertilizers

\begin{tabular}{l|c|c|c}
\hline \multicolumn{1}{c|}{ Analysis } & Soil & Poultry & Farmyard \\
\hline PH & 7.86 & 7.30 & 8.15 \\
Organic matter \% & 0.63 & 28.11 & 17.10 \\
Total nitrogen \% & 0.36 & 1.51 & 0.92 \\
Calcium carbonate \% & 12.01 & 5.80 & 6.00 \\
EC, mmohs / cm & 4.55 & 7.10 & 1.90 \\
P\% & 0.040 & 0.16 & 0.26 \\
K\% & 0.063 & 0.86 & 1.00 \\
Fe ppm & 4.36 & 8430.81 & 25790.0 \\
Mn ppm & 2.20 & 200.10 & 330.81 \\
Zn ppm & 0.31 & 777.95 & 82.87 \\
Cu ppm & 1.20 & 42.90 & 40.50 \\
\hline
\end{tabular}

Broad bean seeds variety Giza 843, were obtained from Agricultural research center, Ministry of Agriculture, Egypt. Seeds of plants were sown on November $4^{\text {th }}$ in the two seasons of 2017 / 2018 and 2018 / 2019. The experimental layout used was completely randomized block system. Each treatment replicated three times. Each replicate contained three units the experimental unit contained five ridges $3.5 \mathrm{~m}$ in length and $0.6 \mathrm{~m}$ width. The normal cultural practices for growing broad bean plants were applied.

\section{Growth parameters:}

Different growth parameters were determined at the age of 125 days, as follow, i.e. plant height $(\mathrm{cm})$, number of main stem internodes / plant, area of the seven the leaf (leaflets blade) from the apex of plant (fully expanded leaf), using an area meter, model Li3000 from Li CORC, USA, number of branches / plant and dry weight of shoots (main stem + branch) / plant.

\section{Yield and components:}

At harvest stage (aged 150 days), number of pods / plant (main stem + branches), number and weight of seeds / plant, weight of 100 seeds $(\mathrm{g})$ and weight of seed yield / plant $(\mathrm{g})$ were determined.

\section{Chemical analysis:}

The following chemical constituents were determined in both two seasons in leaves and seeds.

a- Plant pigments (Chlorophyll a, b and carotenoids) were extracted from fresh leaves and determined calorimetrically as $\mu \mathrm{g} / \mathrm{g}$ fresh leaves according to the method described by[16] .

b- Crude protein was calculated by N \% X 6.25 in dry broad bean seeds.

c- Total free amino acids were determined calorimetrically according to the method described by [17].

d- Total carbohydrates were determined calorimetrically according to the method described by [18], total and reducing sugars were determined according to[19], non-soluble carbohydrates were obtained by subtracting total sugars from total carbohydrates and recorded as $\mathrm{mg} / \mathrm{g}$ dry weight.

e- Total soluble phenols were determined according to[20] . 
f- Total indoles were determined according to[21] .

g- Minerals, total nitrogen \% was determined, using the Orange $\mathrm{G}$ dye according to the methods described by [22], phosphorus \% was determined according to[19], potassium \% was determent according to [23] by flame photometer.

\section{Statistical analysis:}

Analysis of variance of in the two seasons was carried out by suing randomly complete block design according to[24]. The differences between treatment means were compared by L.S.D test for significance at 0.05 level of probability.

\section{Results and Discussion}

\section{1- Growth parameters:}

Data presented in Table ( $2 \& 3$ ) show that, growth parameters of broad bean plant represented in plant height, number of internodes / main stem, number of branches / plant, leaf area and dry weight / plant were greatly improved by mineral fertilization in presence of organic fertilizers at different rates. The highest increases in growth parameters were observed in fertilized plants with highest the rates of mineral fertilizers $(50 \mathrm{~kg} / \mathrm{fed}$. of ammonium nitrate $33.5 \% \mathrm{~N}, 200 \mathrm{~kg} / \mathrm{fed}$. calcium superphosphate $15.5 \% \mathrm{P} 2 \mathrm{O} 5$ and $50 \mathrm{~kg} / \mathrm{fed}$. potassium sulphate $48 \% \mathrm{~K} 2 \mathrm{O}$ for broad bean plants) and received, organic fertilizers, mainly poultry manure at its high amount $\left(\mathrm{P}_{2}+100\right)$. These increases recorded 115 and $140.54 \%$ in plant height, 93.75 and $135.71 \%$ in number of internodes / main stem, 250 and $200 \%$ in number of branches / plant, 75.76 and $69.56 \%$ in leaf area and $159.56,147.46 \%$ in dry weight / plant at the first and second seasons respectively in comparison to the unfertilized plants.

\section{2- Yield and its components:}

Results in Table ( $3 \& 4)$ show that, mineral fertilizers in combination with organic fertilizers resulted in a great effect on yield and its components of broad bean plant. The beneficial effect of organic fertilizers was more pronounced with the highest level of mineral fertilizers in comparison to unfertilized plants during the two studied seasons. However, poultry manure in combination with mineral fertilizers was better than farmyard manure. Where, fertilized plant with the highest level of mineral fertilizers in presence of the highest amount of poultry manure was characterized by a greater yield and its components than the other treatments. 
Table 2. Effect of different rates of organic and inorganic fertilizers on growth parameters of broad beans (Vicia faba L.) plants grown in

\begin{tabular}{|c|c|c|c|c|c|c|c|c|c|}
\hline \multicolumn{2}{|c|}{ Treatments } & \multicolumn{2}{|c|}{$\begin{array}{l}\text { Dry weight / } \\
\text { plant (g) }\end{array}$} & \multicolumn{2}{|c|}{$\begin{array}{c}\text { Leaf area } \\
\left(\mathrm{cm}^{2}\right)\end{array}$} & \multicolumn{2}{|c|}{$\begin{array}{c}\text { No. of } \\
\text { branches }\end{array}$} & \multicolumn{2}{|c|}{$\begin{array}{c}\text { No. of } \\
\text { internodes }\end{array}$} \\
\hline & & 2018 & 2019 & 2018 & 2019 & 2018 & 2019 & 2018 & 2019 \\
\hline \multirow{3}{*}{$\begin{array}{l}\text { Without } \\
\text { organic } \\
\text { manure }\end{array}$} & & & & & & & & & \\
\hline & & 5.21 & 5.01 & 48.2 & 51. & 2.00 & 2.25 & 19.0 & 20.0 \\
\hline & & 7.58 & 7.85 & 69.4 & 72.0 & 2.50 & & 28.0 & 25.0 \\
\hline \multirow{3}{*}{$\begin{array}{l}\text { Poultry } \\
\text { manure } \\
4 \text { tons/fed. } \\
\mathrm{P}_{1}\end{array}$} & & & & & & 1.50 & & 17.0 & 18.0 \\
\hline & $50 \%$ & 8.92 & 8.33 & 58.9 & 59.5 & 1.75 & 2.00 & 20.0 & 22.0 \\
\hline & & 10.63 & 10.13 & 72.8 & 75.3 & 2.75 & 2.75 & 29.0 & 32.0 \\
\hline \multirow{3}{*}{$\begin{array}{l}\text { Poultry } \\
\text { manure } \\
8 \text { tons/fed. } \\
\mathrm{P}_{2}\end{array}$} & & & 6.81 & & 48.2 & 2.00 & & 19.0 & 18.0 \\
\hline & 0 & 9.35 & 8.99 & 62.2 & 60.1 & 2.50 & 2.75 & 22.0 & 20.0 \\
\hline & & & & 74.7 & & 3.50 & & 31.0 & 33.0 \\
\hline \multirow{3}{*}{$\begin{array}{l}\text { Farmyard } \\
\text { manure } \\
\text { 4tons/fed. } \\
\mathrm{F}_{1}\end{array}$} & & נת. & 5.75 & 46.1 & 49.7 & 1.75 & 1.50 & 16.5 & 18.0 \\
\hline & & 8.00 & 7.85 & 55.0 & 58.1 & 1.75 & 2.00 & 20.0 & 21.0 \\
\hline & & 10.21 & 9.98 & 71.8 & 73.2 & 2.25 & 2.25 & 28.0 & 25.0 \\
\hline \multirow{3}{*}{$\begin{array}{l}\text { Farmyard } \\
\text { manure } \\
\text { 8tons/fed. } \\
\mathrm{F}_{2}\end{array}$} & & & & 52.0 & 55.8 & 1.75 & 2.00 & 18.0 & 20.0 \\
\hline & & 9.00 & 8.88 & 60.5 & 63.7 & 2.50 & 2.50 & 21.0 & 23.0 \\
\hline & $100 \%$ & 11.33 & 11.03 & 72.3 & 70.9 & 3.00 & 3.25 & 29.0 & 31.0 \\
\hline \multicolumn{2}{|l|}{ L.S.D. $5 \%$} & 0.01 & 0.20 & 0.21 & 0.37 & 0.75 & 0.75 & 1.25 & 0.58 \\
\hline
\end{tabular}

At this treatment, number of pods / plant, number of seeds / pod, weight of seeds / pods, weight of seeds / plant and weight of 100 seeds were significantly increased by 356.25, 100.0, 271.43, 554.66 and $85.15 \%$ in comparison to unfertilized plants at the first season. Similar trend was observed in the second season (Table 3\&4). Also, farmyard manure in combination with mineral fertilizers, each at the highest level resulted in improving yield and its components but to a lesser extent in comparison to poultry manure. 
Table 3. Effect of different rates of organic and inorganic fertilizers on growth parameters and yield and its components of broad beans (Vicia faba L.) plants grown in calcareous soil

\begin{tabular}{|c|c|c|c|c|c|c|c|c|c|}
\hline \multicolumn{2}{|c|}{ Treatments } & \multicolumn{2}{|c|}{$\begin{array}{l}\text { Plant height } \\
\text { (cm) }\end{array}$} & \multicolumn{2}{|c|}{$\begin{array}{l}\text { Weight of } \\
\text { yield / plant } \\
\text { (g) }\end{array}$} & \multicolumn{2}{|c|}{$\begin{array}{c}\text { Weight of } \\
100 \text { seeds }(\mathrm{g})\end{array}$} & \multicolumn{2}{|c|}{$\begin{array}{c}\text { No. of seeds } \\
\text { / pod }\end{array}$} \\
\hline $\begin{array}{l}\text { Organic } \\
\text { fertilizer }\end{array}$ & rtilizer & 2018 & 2019 & 2018 & 2019 & 2018 & 2019 & 2018 & 2019 \\
\hline \multirow{3}{*}{$\begin{array}{l}\text { Without } \\
\text { organic } \\
\text { manure }\end{array}$} & & & & 15.00 & 20.15 & 50.51 & & & \\
\hline & $50 \%$ & 65.0 & 60.0 & 40.21 & 43.25 & 62.50 & 66.01 & 3.50 & 3.75 \\
\hline & $100 \%$ & 89.5 & 93.0 & 49.62 & 53.14 & 70.81 & 72.11 & 3.75 & 3.75 \\
\hline \multirow{3}{*}{$\begin{array}{l}\text { Poultry } \\
\text { manure } \\
\text { 4tons/fed. } \\
\mathrm{P}_{1} \\
\end{array}$} & & 43.0 & 40.0 & 28.50 & 25.15 & 55.32 & 60.33 & 3.00 & 2.75 \\
\hline & $50 \%$ & 68.0 & 71.0 & 58.50 & 66.12 & 69.95 & 70.11 & 4.00 & 4.25 \\
\hline & $100 \%$ & 80.0 & 85.0 & 86.50 & 93.15 & 82.15 & 85.13 & 4.50 & 4.75 \\
\hline \multirow{3}{*}{$\begin{array}{l}\text { Poultry } \\
\text { manure } \\
\text { 8tons/fed. } \\
\mathrm{P}_{2}\end{array}$} & Zero & 48.0 & 43.0 & 30.21 & 35.22 & 66.20 & 65.01 & 3.50 & 3.25 \\
\hline & $50 \%$ & 70.0 & 75.0 & 69.72 & 69.21 & 82.10 & 80.11 & 4.50 & 4.75 \\
\hline & $100 \%$ & 86.0 & 89.0 & 98.20 & 95.22 & 93.52 & 95.00 & 5.00 & 5.25 \\
\hline \multirow{3}{*}{$\begin{array}{l}\text { Farmyard } \\
\text { manure } \\
\text { 4tons/fed. } \\
\mathrm{F}_{1}\end{array}$} & & 42.0 & 40.0 & 23.70 & 25.33 & 55.00 & 51.00 & 3.00 & 2.75 \\
\hline & $50 \%$ & & 61.0 & 50.52 & 52.20 & 65.61 & 62.33 & 3.75 & 3.25 \\
\hline & $100 \%$ & 72.0 & 69.0 & 80.00 & 86.11 & 80.00 & 82.24 & 4.00 & 3.75 \\
\hline \multirow{3}{*}{$\begin{array}{l}\text { Farmyard } \\
\text { manure } \\
\text { 8tons/fed. } \\
\mathrm{F}_{2}\end{array}$} & Zero & 46.0 & 47.0 & 28.12 & 32.14 & 62.75 & 64.11 & 3.25 & 3.50 \\
\hline & $50 \%$ & 59.0 & 55.0 & 62.41 & 65.11 & 78.30 & 80.31 & 4.25 & 4.00 \\
\hline & $100 \%$ & 84.0 & 81.0 & 90.22 & 93.64 & 90.02 & 92.21 & 5.00 & 5.25 \\
\hline \multicolumn{2}{|l|}{ L.S.D. $5 \%$} & 4.64 & 3.60 & 0.21 & 0.57 & 0.81 & 0.98 & 1.09 & 1.11 \\
\hline
\end{tabular}

\section{3- Chemical constituents:}

\section{A- Pigments:}

Data recorded in Table (4\&5) clearly show that, organic fertilizers had a simulative effect on chemical constituents of broad bean plants specialty in combination with the highest rate of mineral fertilizers. Chemical constituents represented in chlorophyll $a, b$ and carotenoids were gradually increased with increasing organic and mineral fertilizers amounts each alone or in combination together. 
Table 4. Effect of different rates of organic and inorganic fertilizers on yield and its components and chemical constituents of broad beans (Vicia faba L.) leaves grown in calcareous soil

\begin{tabular}{|l|l|c|c|c|c|c|c|c|c|}
\hline \multicolumn{2}{|c|}{ Treatments } & \multicolumn{2}{c|}{$\begin{array}{c}\text { No. of pods / } \\
\text { plant }\end{array}$} & \multicolumn{2}{c|}{$\begin{array}{c}\text { Weight of } \\
\text { seeds / pod } \\
\text { (g) }\end{array}$} & \multicolumn{2}{c|}{$\begin{array}{c}\text { Chlorophyll } \\
\text { A ug / g }\end{array}$} & \multicolumn{2}{c|}{$\begin{array}{c}\text { Chlorophyll } \\
\text { B ug / g F.W }\end{array}$} \\
\hline $\begin{array}{l}\text { Organic } \\
\text { fertilizer }\end{array}$ & $\begin{array}{l}\text { Mineral } \\
\text { fertilizer }\end{array}$ & 2018 & 2019 & 2018 & 2019 & 2018 & 2019 & 2018 & 2019 \\
\hline $\begin{array}{l}\text { Without } \\
\text { organic } \\
\text { manure }\end{array}$ & Control & 4.00 & 4.25 & 1.26 & 1.32 & 570 & 580 & 500 & 511 \\
\hline $\begin{array}{l}\text { Poultry } \\
\text { manure }\end{array}$ & $100 \%$ & 11.50 & 12.00 & 2.66 & 2.70 & 635 & 633 & 600 & 589 \\
4tons/fed. & Zero & 6.75 & 6.50 & 1.66 & 1.66 & 600 & 610 & 563 & 570 \\
P1 & $100 \%$ & 10.50 & 10.75 & 2.80 & 2.98 & 648 & 655 & 603 & 621 \\
\hline $\begin{array}{l}\text { Poultry } \\
\text { manure }\end{array}$ & Zero & 8.00 & 7.75 & 2.32 & 2.11 & 652 & 660 & 608 & 619 \\
8tons/fed. & $50 \%$ & 12.50 & 13.00 & 3.69 & 3.81 & 675 & 673 & 636 & 643 \\
P
\end{tabular}

The best results were attained with the highest rate of poultry manure (8tons/fed) in combination with the highest rate of NPK fertilizers, followed by farmyard manure at its high amount in combination with mineral fertilizers. This trend was similar during the two studied seasons.

\section{B- Crude protein and total free amino acids concentrations:}

Data recorded in Table (5) show that, organic fertilizers had a stimulative effect on chemical constituents of broad bean plants specialty in combination with the highest rate of mineral fertilizers. Chemical constituents represented in crude proteins and total free amino acids concentrations were gradually increased with increasing organic and mineral fertilizers amounts each alone or in combination to gather. The best results were attained with the highest rate of poultry manure in combination with the highest rate of mineral fertilizers, followed by farmyard manure at its high amount in combination with mineral fertilizers. This trend was similar during the two studied seasons. The effect of organic fertilizers was more pronounced on free amino acid concentrations than the other chemical constituents. Where, the highest rates of poultry manure in combination with the highest rate of mineral fertilizers caused maximum increase of free amino acids concentration at the first season $(301.79 \%$ and $43.73 \%)$ and the second one $(248.46 \%$ and $43.81 \%$ ) for leaves and seeds respectively in comparison to the control (Table, 5). 


\section{C- Total phenols:}

Data recorded in Table (5) show that total phenols of both leaves and seeds were greatly affected by the different kinds and amounts of the both two organic fertilizers either alone or in combination with NPK fertilizers. Increasing the rate of NPK fertilizers significantly decreased total phenols of leaves and seeds but to a lesser extent in comparison to organic fertilizer. The kinds of organic fertilizer (poultry manure and farmyard manure) gave the best results especially poultry manure at its maximum rate in combination with NPK fertilizers. Leaves and seeds of broad bean plants fertilized by poultry manure contained lower total phenols concentrations than the other treatments. Moreover, increasing poultry manure rate caused a high decrease in total phenols counteractions of leaves and seed.

Table 5. Effect of different rates of organic and inorganic fertilizers on chemical constituents of broad beans (Vicia faba L.) leaves grown in calcareous soil

\begin{tabular}{|c|c|c|c|c|c|c|c|c|c|}
\hline \multicolumn{2}{|c|}{ Treatments } & \multicolumn{2}{|c|}{$\begin{array}{l}\text { Carotienoids } \\
\text { ug / g F.W }\end{array}$} & \multicolumn{2}{|c|}{$\begin{array}{c}\text { Crude } \\
\text { protein \% }\end{array}$} & \multicolumn{2}{|c|}{$\begin{array}{l}\text { Total amino } \\
\text { acids mg / g } \\
\text { D.W }\end{array}$} & \multicolumn{2}{|c|}{$\begin{array}{l}\text { Total phenols } \\
\text { mg / g D.W }\end{array}$} \\
\hline $\begin{array}{l}\text { Organic } \\
\text { fertilizer }\end{array}$ & & 018 & 019 & 2018 & 2019 & 2018 & 2019 & 2018 & 2019 \\
\hline \multirow{3}{*}{$\begin{array}{l}\text { Without } \\
\text { organic } \\
\text { manure }\end{array}$} & & & & & & 4.46 & 5.10 & 12.44 & 13.21 \\
\hline & & 45.60 & 47.25 & 18.44 & 18.69 & 6.12 & 6.99 & 10.45 & 11.05 \\
\hline & & 52.80 & 56.90 & 20.00 & 19.69 & 8.96 & 9.12 & 7.47 & 7.63 \\
\hline \multirow{3}{*}{$\begin{array}{l}\text { Poultry } \\
\text { manure } \\
4 \text { tons/fed. } \\
\mathrm{P}_{1}\end{array}$} & & & & & & 5.97 & 6.21 & 11.31 & 12.05 \\
\hline & & 55.60 & 58.66 & 18.50 & 19.19 & 8.82 & 9.03 & 8.52 & 9.29 \\
\hline & & 8 & 7 & 23.06 & 23.49 & 10.45 & 11.01 & 7.00 & 6.99 \\
\hline \multirow{3}{*}{$\begin{array}{l}\text { Poultry } \\
\text { manure } \\
\text { 8tons/fed. } \\
\mathrm{P}_{2} \\
\end{array}$} & & 4.60 & & 18.75 & 18.69 & 7.13 & 8.01 & 9.85 & 10.33 \\
\hline & & 0.20 & 66.11 & 21.38 & 21.44 & 12.44 & 11.99 & 7.16 & 8.33 \\
\hline & $100 \%$ & & & & 23.69 & 17.92 & 18.05 & 5.42 & 6.25 \\
\hline \multirow{3}{*}{$\begin{array}{l}\text { Farmyard } \\
\text { manure } \\
\text { 4tons/fed. } \\
\mathrm{F}_{1}\end{array}$} & & & & & 16.63 & 5.53 & 6.33 & 9.50 & 9.83 \\
\hline & $50 \%$ & & & 18.50 & 18.69 & 8.00 & 8.31 & 7.86 & 6.89 \\
\hline & & & & & & 9.51 & 9.45 & 7.28 & 6.38 \\
\hline \multirow{3}{*}{$\begin{array}{l}\text { Farmyard } \\
\text { manure } \\
8 \text { tons/fed. } \\
\mathrm{F}_{2}\end{array}$} & & & & 18.13 & 18.06 & 6.50 & 6.99 & 9.12 & 8.96 \\
\hline & $50 \%$ & 57.30 & 60.12 & 20.69 & 21.31 & 10.38 & 11.08 & 7.00 & 6.13 \\
\hline & $100 \%$ & 78.10 & 75.21 & 23.13 & 23.63 & 14.92 & 15.63 & 6.38 & 5.88 \\
\hline \multicolumn{2}{|l|}{ L.S.D. $5 \%$} & 6.27 & 2.54 & 0.68 & 0.75 & 0.28 & 0.39 & 1.04 & 0.31 \\
\hline
\end{tabular}

\section{D-Carbohydrates:}

Data recorded in Table $(6,7 \& 8)$ Cleary show that, as expected, organic fertilizers had a positive effect on the chemical constituents of broad bean leaves and seeds either alone or in combination with mineral fertilizers. The trend at the first season resembles that at the second one. Among the organic fertilizer types and their amount, variation in mentioned chemical constituents was observed. In this respect, poultry organic fertilizer gave the best results either alone or in combination with mineral fertilizer in comparison to farmyard organic fertilizer under the same conditions. Where, the highest increase of the chemical constituents mentioned previously were 
obtained by using the highest rate of poultry manure in combination with the highest rate of mineral fertilizers followed by farmyard manure under the same conditions. At the first season, these increments over control recorded $(83.37,67.57 \%$ for total carbohydrates; $107.79,84.66 \%$ for total sugar; 138.52, $113.77 \%$ for reducing sugar; 73.28, $60.52 \%$ for non-soluble carbohydrates concentrations) for leaves and $(83.37,67357 \%$ for total carbohydrates, $107.79,84.66 \%$ for total sugars, $138.52,113.77 \%$ for reducing sugars and $73.28,60.52 \%$ for non-soluble carbohydrates concentration) for seeds at $\mathrm{P}_{2}$ and $\mathrm{F}_{2}$ treatments, respectively each in combination with mineral fertilizers at the highest rate $(100 \%)$. On the other hand total phenols concentration was decreased by 56.43 and $48.71 \%$ at $\mathrm{P}_{2}$ and $\mathrm{F} 2$, respectively each in combination with mineral fertilizers similar trend was obtained at the second season (Table 5). It is clear from the results in Table $(5,6,7,8 \& 9)$ that chemical constituent of leaves and seeds of broad bean plants were improved greatly under organic fertilizer conditions especially poultry manure.

Table 6. Effect of different rates of organic and inorganic fertilizers on chemical constituents of broad beans (Vicia faba L.) leaves grown in calcareous soil

\begin{tabular}{|c|c|c|c|c|c|c|c|c|c|}
\hline \multicolumn{2}{|c|}{ Treatments } & \multicolumn{2}{|c|}{$\begin{array}{l}\text { Total sugars } \\
\text { mg / g D.W }\end{array}$} & \multicolumn{2}{|c|}{$\begin{array}{l}\text { Reducing } \\
\text { sugars mg / } \\
\text { g D.W }\end{array}$} & \multicolumn{2}{|c|}{$\begin{array}{l}\text { Non soluble } \\
\text { carbohydrates } \\
\text { mg / g D.W }\end{array}$} & \multicolumn{2}{|c|}{$\begin{array}{c}\text { Total } \\
\text { carbohydrates } \\
\text { mg / g D.W }\end{array}$} \\
\hline $\begin{array}{l}\text { Organic } \\
\text { fertilizer }\end{array}$ & & 2018 & 2019 & 2018 & 2019 & 2018 & 2019 & 2018 & 2019 \\
\hline \multirow{3}{*}{$\begin{array}{l}\text { Without } \\
\text { organic } \\
\text { manure }\end{array}$} & introl & & 25.44 & 18.95 & 16.33 & 69.02 & 86.11 & 97.51 & 111.55 \\
\hline & $50 \%$ & 32.65 & 33.55 & 24.44 & 25.22 & 103.55 & 99.60 & 136.2 & 133.15 \\
\hline & $0 \%$ & 40.81 & 44.11 & 33.18 & 31.11 & 116.59 & 115.01 & 157.4 & 159.12 \\
\hline \multirow{3}{*}{$\begin{array}{l}\text { Poultry } \\
\text { manure } \\
4 \text { tons/fed. } \\
\mathrm{P}_{1}\end{array}$} & Zero & 38.50 & 39.90 & 23.71 & 26.13 & 78.10 & 81.11 & 116.6 & 121.00 \\
\hline & $50 \%$ & 46.71 & 48.13 & 30.38 & 31.18 & 93.49 & 91.86 & 140.2 & 139.99 \\
\hline & $100 \%$ & 50.55 & 50.16 & 40.51 & 44.17 & 117.55 & 108.99 & 168.1 & 159.15 \\
\hline \multirow{3}{*}{$\begin{array}{l}\text { Poultry } \\
\text { manure } \\
8 \text { tons/fed. } \\
\mathrm{P}_{2}\end{array}$} & Zero & 40.00 & 43.12 & 29.23 & 28.35 & 88.00 & 88.02 & 128.0 & 131.14 \\
\hline & $50 \%$ & 49.51 & 49.14 & 39.61 & 41.14 & 99.20 & 106.11 & 148.2 & 155.25 \\
\hline & $100 \%$ & 59.20 & 56.20 & 45.20 & 45.13 & 119.60 & 116.94 & 178.8 & 173.14 \\
\hline \multirow{3}{*}{$\begin{array}{l}\text { Farmyard } \\
\text { manure } \\
4 \text { tons/fed. } \\
\mathrm{F}_{1} \\
\end{array}$} & Zero & 35.00 & 36.11 & 22.19 & 23.18 & 75.20 & 83.20 & 110.2 & 119.31 \\
\hline & $50 \%$ & 42.10 & 43.12 & 27.20 & 26.14 & 88.50 & 93.41 & 130.6 & 136.53 \\
\hline & $100 \%$ & 46.22 & 48.33 & 36.35 & 38.33 & 109.38 & 110.88 & 155.6 & 159.21 \\
\hline \multirow{3}{*}{$\begin{array}{l}\text { Farmyard } \\
\text { manure } \\
\text { 8tons/fed. } \\
\mathrm{F}_{2}\end{array}$} & Zero & 38.21 & 37.11 & 25.51 & 29.14 & 82.49 & 91.01 & 120.7 & 128.12 \\
\hline & $50 \%$ & 44.50 & 45.17 & 31.18 & 33.15 & 93.80 & 92.02 & 138.3 & 137.19 \\
\hline & $100 \%$ & 52.61 & 54.17 & 40.51 & 41.14 & 110.79 & 111.08 & 163.4 & 165.25 \\
\hline \multicolumn{2}{|c|}{ L.S.D. 5\% } & 1.51 & 1.48 & 0.87 & 1.40 & 2.03 & 1.65 & 1.72 & 1.73 \\
\hline
\end{tabular}

\section{E-Total indoles:}

Data in both two seasons presented in Table (8) indicate that, leaves of bread bean plant contained a high concentration of total indoles under organic fertilizers conditions comparing to unfertilized plants. Moreover, the total indoles were significantly increased with increasing organic fertilizer rate. Similar results were obtained with increasing NPK fertilizer amounts but to a lesser extent. The combination between organic and NPK fertilizers gave the best results, especially poultry manure. Maximum increase was observed in total indole concentration (35.15 and 31.68 \%) at $\mathrm{P}_{2}$ and $\mathrm{F}_{2}$ treatments, each in combination with the highest rate $(100 \%)$ of NPK fertilizers. 
Table 7. Effect of different rates of organic and inorganic fertilizers on chemical constituents of broad beans (Vicia faba L.) seeds grown in calcareous soil

\begin{tabular}{|c|c|c|c|c|c|c|c|}
\hline \multicolumn{2}{|c|}{ Treatments } & \multicolumn{2}{|c|}{$\begin{array}{c}\text { Crude } \\
\text { protein \% }\end{array}$} & \multicolumn{2}{|c|}{$\begin{array}{c}\text { Total free } \\
\text { amino acids } \\
\text { mg / g D.W }\end{array}$} & \multicolumn{2}{|c|}{$\begin{array}{l}\text { Total soluble } \\
\text { carbohydrates } \\
\text { mg / g D.W }\end{array}$} \\
\hline $\begin{array}{l}\text { Organic } \\
\text { fertilizer }\end{array}$ & $\begin{array}{l}\text { Mineral } \\
\text { fertilizer }\end{array}$ & 2018 & 2019 & 2018 & 2019 & 2018 & 2019 \\
\hline \multirow{3}{*}{$\begin{array}{l}\text { Without } \\
\text { organic } \\
\text { manure }\end{array}$} & Control & 25.50 & 23.13 & 30.76 & 30.13 & 172.05 & 165.30 \\
\hline & $50 \%$ & 25.50 & 25.15 & 28.51 & 29.21 & 175.21 & 170.10 \\
\hline & $100 \%$ & 25.69 & 26.01 & 26.42 & 25.33 & 178.70 & 180.13 \\
\hline \multirow{3}{*}{$\begin{array}{l}\text { Poultry } \\
\text { manure } \\
\text { 4tons/fed. } \\
\mathrm{P}_{1}\end{array}$} & Zero & 26.13 & 26.93 & 24.81 & 23.19 & 177.31 & 180.20 \\
\hline & $50 \%$ & 26.56 & 26.99 & 23.00 & 23.05 & 180.20 & 181.20 \\
\hline & $100 \%$ & 27.69 & 28.01 & 21.15 & 22.13 & 182.60 & 186.30 \\
\hline \multirow{3}{*}{$\begin{array}{l}\text { Poultry } \\
\text { manure } \\
8 \text { tons/fed. } \\
\mathrm{P}_{2}\end{array}$} & Zero & 26.75 & 26.92 & 20.75 & 21.25 & 178.65 & 182.14 \\
\hline & $50 \%$ & 28.13 & 28.83 & 19.28 & 19.99 & 181.22 & 185.25 \\
\hline & $100 \%$ & 29.50 & 29.00 & 17.31 & 16.93 & 184.52 & 185.65 \\
\hline \multirow{3}{*}{$\begin{array}{l}\text { Farmyard } \\
\text { manure } \\
\text { 4tons/fed. } \\
F_{1}\end{array}$} & Zero & 25.31 & 25.69 & 28.22 & 29.39 & 174.51 & 169.21 \\
\hline & $50 \%$ & 25.75 & 25.99 & 27.05 & 26.13 & 176.77 & 174.33 \\
\hline & $100 \%$ & 26.38 & 27.00 & 25.16 & 23.21 & 179.50 & 183.25 \\
\hline \multirow{3}{*}{$\begin{array}{l}\text { Farmyard } \\
\text { manure } \\
8 \text { tons/fed. } \\
\mathrm{F}_{2}\end{array}$} & Zero & 25.88 & 24.99 & 26.71 & 26.11 & 176.40 & 171.33 \\
\hline & $50 \%$ & 26.56 & 27.01 & 25.00 & 24.11 & 179.00 & 183.20 \\
\hline & $100 \%$ & 27.19 & 27.25 & 23.24 & 22.21 & 183.61 & 185.17 \\
\hline \multicolumn{2}{|l|}{ L.S.D. $5 \%$} & 1.08 & 2.01 & 1.35 & 2.41 & 3.15 & 4.70 \\
\hline
\end{tabular}


Table 8. Effect of different rates of organic and inorganic fertilizers on chemical constituents of broad beans (Vicia faba L.) seeds and leaves grown in calcareous soil

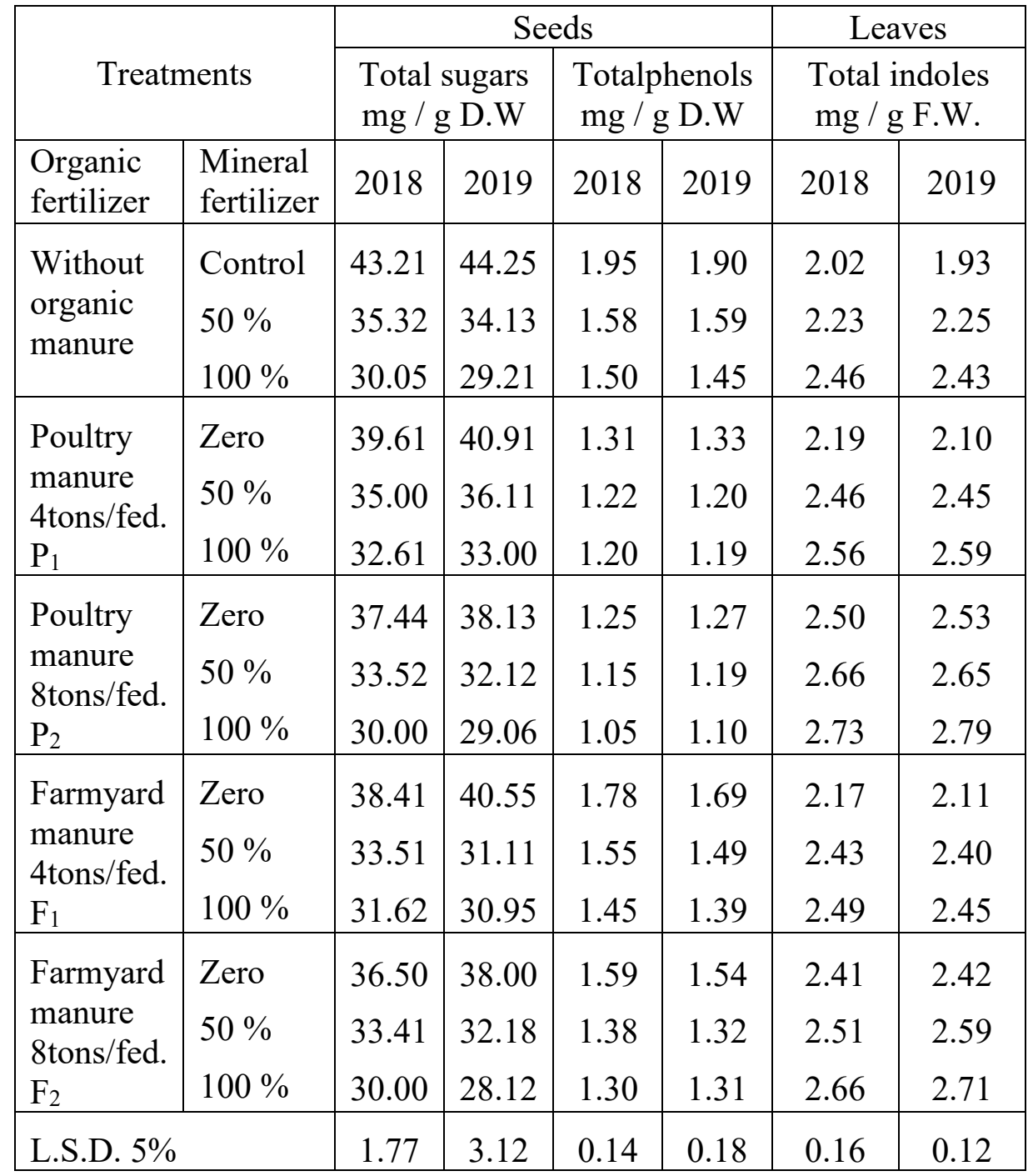

\section{E. Nitrogen, phosphorus and potassium concentrations:}

Data in both two seasons presented in Table (9) indicate that, leaves of bread bean plant contained a high concentration of nitrogen, phosphors and potassium under organic fertilizers conditions comparing to unfertilized plants. Moreover, the present chemical constitutes were significantly increased with increasing organic fertilizer rates. Similar results were obtained with increasing NPK fertilizer amounts but to a lesser extent. The combination between organic and mineral fertilizers gave the best results, especially poultry manure. Maximum increase was observed in phosphorus concentration (66.67 and $50.0 \%$ ) followed by nitrogen concentration (57.26 and $56.85 \%$ ), at $\mathrm{P}_{2}$ and $\mathrm{F}_{2}$ treatments, each in combination with the highest rate (100\%) of NPK fertilizers. The present results show that, increasing chemical constituents represented in, nitrogen, phosphorus and potassium concentrations due to the combination of NPK and organic fertilization. 
Table 9. Effect of different rates of organic and inorganic fertilizers on chemical constituents of broad beans (Vicia faba L.) leaves grown in calcareous soil

\begin{tabular}{|c|c|c|c|c|c|c|c|}
\hline \multicolumn{2}{|c|}{ Treatments } & \multicolumn{2}{|c|}{ Nitrogen $\%$} & \multicolumn{2}{|c|}{ Phosphorus \% } & \multicolumn{2}{|c|}{ Potassium \% } \\
\hline $\begin{array}{l}\text { Organic } \\
\text { fertilizer }\end{array}$ & $\begin{array}{l}\text { Mineral } \\
\text { fertilizer }\end{array}$ & 2018 & 2019 & 2018 & 2019 & 2018 & 2019 \\
\hline \multirow{3}{*}{$\begin{array}{l}\text { Without } \\
\text { organic } \\
\text { manure }\end{array}$} & Control & 2.50 & 2.41 & 0.18 & 0.16 & 2.20 & 2.15 \\
\hline & $50 \%$ & 2.95 & 2.99 & 0.21 & 0.22 & 2.31 & 2.32 \\
\hline & $100 \%$ & 3.20 & 3.15 & 0.23 & 0.25 & 2.42 & 2.39 \\
\hline \multirow{3}{*}{$\begin{array}{l}\text { Poultry } \\
\text { manure } \\
\text { 4tons/fed. } \\
\mathrm{P}_{1}\end{array}$} & Zero & 2.84 & 2.78 & 0.22 & 0.22 & 2.32 & 2.31 \\
\hline & $50 \%$ & 2.99 & 3.07 & 0.25 & 0.24 & 2.45 & 2.45 \\
\hline & $100 \%$ & 3.69 & 3.75 & 0.27 & 0.28 & 2.49 & 2.46 \\
\hline \multirow{3}{*}{$\begin{array}{l}\text { Poultry } \\
\text { manure } \\
\text { 8tons/fed. } \\
\mathrm{P}_{2}\end{array}$} & Zero & 3.00 & 2.99 & 0.24 & 0.25 & 2.35 & 2.34 \\
\hline & $50 \%$ & 3.42 & 3.43 & 0.28 & 0.27 & 2.49 & 2.50 \\
\hline & $100 \%$ & 3.85 & 2.79 & 0.30 & 0.31 & 2.55 & 2.53 \\
\hline \multirow{3}{*}{$\begin{array}{l}\text { Farmyard } \\
\text { manure } \\
\text { 4tons/fed. } \\
\mathrm{F}_{1} \\
\end{array}$} & Zero & 2.70 & 2.66 & 0.21 & 0.22 & 2.30 & 2.28 \\
\hline & $50 \%$ & 2.96 & 2.99 & 0.23 & 0.24 & 2.42 & 2.43 \\
\hline & $100 \%$ & 3.55 & 3.60 & 0.24 & 0.24 & 2.46 & 2.48 \\
\hline \multirow{3}{*}{$\begin{array}{l}\text { Farmyard } \\
\text { manure } \\
\text { 8tons/fed. } \\
\mathrm{F}_{2}\end{array}$} & Zero & 2.90 & 2.89 & 0.23 & 0.22 & 2.33 & 2.31 \\
\hline & $50 \%$ & 3.31 & 3.41 & 0.24 & 0.25 & 2.40 & 2.42 \\
\hline & $100 \%$ & 3.70 & 3.78 & 0.27 & 0.29 & 2.49 & 2.51 \\
\hline \multicolumn{2}{|l|}{ L.S.D. 5\% } & 0.12 & 0.09 & 0.01 & 0.01 & 0.09 & 0.05 \\
\hline
\end{tabular}

\section{Discussion}

Fertilizing the plants with organic manures (poultry or farmyard) combined with some mineral nutrients (NPK) resulted in vigorous growth as well as highly productivity of seeds with good quality. An increasing the measured growth characters (plant height etc...) was due to that these fertilizers resulting in more release of available nutrients (micro or macro ones) to be absorbed by the tested plants[14\&25].The important role of $\mathrm{N}$ in protein, chlorophyll, enzymes and energy transfer substances (ADP and ATP) were early recorded by[26].The results showed highly concentrations of chemical constituents estimated both leaves and seeds of the above mentioned fertilized plants. This finding could be an indication to the high rate of synthesis of these products as indication to the role of organic matter in supplied the plants with nutrient-sufficient, which increases the vegetative parts and thus increase various growth processes such as chlorophyll formation, photosynthesis process as well as the utilization of carbohydrates in the, which utilized in the 219 composition of plant parts and thus decrease of competition and abortion, which led to the increase in the number of seeds per pod, this is consistent with [27]) on common bean and [28] on soya bean. The hormonal balance between the promoters and inhibitors which regulate the different physiological processes in the plants appear to be highly affected by the nutrient status of the plants. These results are in full agreement with those obtained by[29] on brood bean and wheat plants. The above mentioned results lead us to propose that the supplying plants with the organic manures in addition to some major nutrients (N,P,K) lead to high yield of seeds with a good quality. Moreover, organic matter that contains most of the nutrients leads to increase the amount of protein and carbohydrates accumulated in the seed which leads to increase the weight of the seed [30].Also, 
the increase in protein by chemical fertilization (NPK) is attributed to the role of $\mathrm{N}$ and $\mathrm{P}$ in the plant[31\&32]. The increase of protein by applying poultry or farmyard manureis attributed to its contain of amino acids and vitamins and many of the elements [33].This was consistent with [34]. The reason for increasing protein concentration when adding organic fertilizers is due to the high concentration of nutrient elements which is easy to absorb by the plant and conversion to useful substances such as the converts the nitrogen to protein in the plant, which accumulates in the seeds during maturation [26]. The increase in the seed number per pod by chemical fertilizer (NPK) was attributable to the role of phosphorus in increasing the activity and growth of plant roots as well as increasing plant vegetative growth, and to the phosphorus entry in most vehicles energy-rich which is necessary in plant biosynthesis [35]. This was consistent with[36] in broad bean.

\section{Conclusion}

It is clear from the present study that improving growth and yield of broad bean plants grown in newly cultivated land were required fertilized with different rates of organic fertilizers (poultry or farmyard manures) with minerals fertilizers (NPK). The data also show that organic fertilized plants achieved higher values of different growth parameters and chemical constituents of leaves and seeds such as chlorophyll. A, b, carotenoids, crude proteins, total free amino acids, total carbohydrates, total sugars, reducing sugars an non soluble carbohydrates. The highest results were obtained when the plants were fertilized with high rate of poultry manure ( 8 tons) and NPK fertilizers $(50 \mathrm{~kg}$ ammonium nitrate $33.5 \%+200 \mathrm{~kg}$ superphosphate $15.5 \%+50 \mathrm{~kg}$ potassium Sulphate 48\%).

\section{References}

[1] Jasim, A.H. (2007): Effect of foliar fertilization on growth and yield of broad bean Vicia faba L. Alanbar J. Agric. Sci., 5(2):177-182.

[2] Adediran, J.A., Taiwo, L.B., Akande, M.O., Sobulo, R.A. and Idowu, O.J. (2004): Application of organic and inorganic fertilizer for sustainable maize and cowpea yields in Nigeria. J. Plant Nutr., 27(7):1163-1181.

[3] Oad F.C., Buriro U.A. and Agha S.K. ( 2004): Effect of organic and inorganic fertilizer application on maize fodder production. Asian J. Plant Sci., 3(3):375-377.

[4] Abou El- Magd, M.M., El-Bassiony, M. and Fawzy, Z.F. (2006): Effect of organic manure with or without chemical fertilizers on growth, yield and quality of some varieties of broccoli plants. J. Appl. Sci. Res., 2(10):791-798.

[5] Ayoola, S.R. and Makinde, E.A. (2009): Maize growth, yield and soil nutrient changes with N-enriched organic fertilizers. African J. Food Agric. Nut. and Develop., 9(1): 580-592.

[6] Sanwal, S.K., Lakminarayana,K., Yadav,R.K., Rai,N., Yadav,D.S. and Mousumi,B. (2007): Effect of organic manures on soil fertility, growth, physiology, yield and quality of turmeric. Indian Journal of Horticulture, 64(4): 444-449.

[7] Jahan,M., Koocheki, A., Nassiri, M. and Dehghanipur, F. (2008): The effect of different cattle manure levels and branch management methods on organic production of Cucurbita pepo L. AmericanEurasian J. Agric. \& Environ. Sci., 4(6): 748-752.

[8] Senjobi, B.A., Peluola, C.O. , Senjobi, C.T. , Lawal, I.O. and Salami, B.T. (2010): Performance of Cochorus olitorius as influenced by soil type and organic manure amendments in Yewa North Local Government Area, Ogun State. African Journal of Biotechnology, 9(33): 5309-5312. 
[9] El-Sherbeny, S.E., Hendawy, S.F., Youssef, A.A., Naguib, N.Y. and Hussein, M.S. (2012): Response of turnip (Brassica rapa) plants to minerals or organic fertilizer treatments. Journal of Applied Sciences Research, 8(2): 628-634.

[10] Ibrahim, H. A., K. and Sherif, M.I. ( 2014): Effect of some organic extracts on essential nutrients uptake of sugar beet under saline conditions. Research Journal of Agriculture and Biological Sciences, 10(1): 53-64.

[11] Murphy, B.W. (2014): Effects of soil organic matter on functional soil properties. Brain W. Murphy. Soil Scientist, Cowra, p.129, GRDC.

[12] Ali, A. H., Shafeek, M.R., Mahmoud, R. A. and El- Desuki, M. (2014): Effect of Various Levels of Organic Fertilizer and Humic Acid on the Growth and Roots Quality of Turnip Plants (Brassica rapa). Current Science International, 3(1): 7-14.

[13] Jasim,A.H. and Mhanna, Q.L.(2014):Effect of some organic fertilizers treatments on dry seed yield of broad been(Vicia faba L.). Scientific Papers. Series A. Agronomy, 2:218-222.

[14] Mekki, B.E.(2016):Effect of bioorganic,chemical fertilizer and their combination on growth yield and some macro and micronutrients contents of faba bean (Vicia faba L.). Bioscience Research, 13(1): 08-14.

[15] Shafeek, M.R. and Shaheen, A. M., Hafez, M.M., Mahmoud, A.R. and Ali, A.H.(2017): Influence of cattle manure levels on the snap bean cultivars grown in sandy soil condition. Middle East J. Appl. Sci., 7(3): 430-438.

[16] Welburn, A. R. and Lichtenthaler, H. (1984): formula and program to determine total caroteniods and chlorophyll $\mathrm{a}$ and $\mathrm{b}$ of leaf extracts in different solvents. In "Advances in photosynthesis Research". (Sybesma C. Ed.) Vol. II, pp. 9 - 19.

[17] Jayarman, J. (1981): Laboratory manual in biochemistry. Wiley Eastern Limited, New York. pp. $61-73$.

[18] Michel, K. A., Gilles, J. K., Hamilton, P. A. and Freed, S. (1956): Colorimetric method for determination of sugars and relate substances. Analytical Chemistry, 28 (3): 350-356.

[19] A.O. A. C. (1995): Official Methods of Analysis published by the A. O. A. C. Washington, D. C., USA.

[20] Snell, F. D. and Snell, C. T. (1953): Colorimetric methods of analysis including some turbimentric and morphalmetric methods. D. Van. Nastrad Company, Inc. New Jersey, Toronto, New York, Landon, 111: 606.

[21] Lasrson, P., Herbo, A., Klunsour, S. and Aasheim, T. (1962): On the biogenesis of some indoles compounds in acetobacter xylimum. Physiol. Plant, 15: $552-565$.

[22] Hafez, A. and Hikkelsen, D. S. (1981): Colorimetric determination of nitrogen for evaluating the nutritional status of rice. Commnu. Soil Sci. and Plant Analysis, 12 (1): 16 69.

[23] Page, A. I., Miller, R. H. and Keeny, T. R. (1982): Methods of soil analysis part 2: 595. Am. Soc. of Agron., Madison WI9.

[24] Gomez, K. A. and Gomez, A. A. (1983): Statistical analysis procedures of agricultural research. Jhon Wiley and Sons, New York, Chichester Brishone. Toranto. Singapore.

[25] Bayu, W., Rethman, N.F.G. Hammers, P.S.and Alemu,G. (2006): Effects of farmyard manure and inorganic fertilizers on sorghum growth, yield and Nitrogen use in a semi arid area of Ethiopia. Journal of plant Nutrition., 29: 391-407. 
[26] Mahmoud, K., Parisa, B. and Reza, O. (2012):Effect of some chemical and biological fertilizers on productivity of a medicinal flax (Linum usitatissimum) plant. Inter. J. Agron. \&Plant Prod. 3 (3):78-83.

[27] Anju, S. and Vijayalakshmi, A. (2013): Residual effects of integrated nutrient management with farmyard manure, coir pith and press mud compost on cluster bean. I.J.S.N., 4(3):405407.

[28] Maheshbabu, R.H., Patil, N.K.B. and Babalad, H.B. (2008): Effect of organic manures on plant growth, seed yield and quality of soybean. Karnataka J. Agric. Sci., 21(2):219-221.

[29] Mahmoud, S.M., Attia, K.K. and El-Desouky, M.M. (2000): Response of pea nut grown on a sandy calcareous soil to inoculation with Bradyhizobium spp. And fertilization with organic manure and some micronutrients. J.Agric. Sci. Mansoura Univ., 25 (1):595-609.

[30] Arjumand, B.S.S., Ananth, N.B. and Puttaiah, E.T. (2013): Effectiveness of farmyard manure, poultry manure and fertilizer -NPK on the growth parameters of french bean (Phaseolus vulgaris L). J. Current Res., 1(1):31-35.

[31] Kovacs, A.B., Vago, I. and Kremper, R. (2008): Growth and yield responses of garden bean (Phaseolus vulgaris L) to nitrogen and sulfur fertilization. Analele UniversitaĠii din Oradea, Fascicula: ProtecĠia Mediului, 13 (4): 93-111.

[32] Kandil H., Gad N. and Abdelhamid M.T. (2013): Effects of different rates of phosphorus and molybdenum application on two varieties common bean. J. Agric. Food. Tech., 3(3)816.

[33] Stirk, W.A., Arthur, G.O., Lourens, A.K., Novod, O., Strnad, M. and Van Staden, J.(2004): Change in cytokinine and auxin concentrations in seaweed concentrates when stores at an elevated temperatures. J. Appl. Phycology., 16:31-39.

[34] Sabh, A.Z. and Shallan, M.A. (2008): Effect of organic Fertilization of Broad Bean (Vicia faba L.) by using different Marine Macro-algae in relation to the morphological characteristics and chemical constituents of the plant. Aust. J. Basic and Appl. Sci., 2(4):1076-1091.

[35] Silva, T.R.B., Lavagnolli, R.R. and Nolla, A. (2011): Zinc and phosphorus fertilization of crambe. J. Food Agric. Environ., 9: 264-267.

[36] Ahmed, M.A. and El-Abagy, H.M.H. (2007): Effect of bio-and mineral phosphorus fertilizer on the growth, productivity and nutritional value of some faba bean (Vicia faba L.) cultivars in newly cultivated land. J. of Appl. Sci. Res3 (6):408-420. 